\title{
Effects of low-level laser therapy on autogenous bone graft stabilized with a new heterologous fibrin sealant
}

\author{
Jéssica Barbosa de Oliveira Gonçalves ${ }^{\mathrm{a}, \mathrm{b}}$, Daniela Vieira Buchaim ${ }^{\mathrm{a}, \mathrm{b}}$, Cleuber Rodrigo de Souza Bueno ${ }^{\mathrm{c}}$, \\ Karina Torres Pomini ${ }^{b}$, Benedito Barraviera ${ }^{d}$, Rui Seabra Ferreira Júnior ${ }^{\mathrm{d}}$, Jesus Carlos Andreo ${ }^{\mathrm{b}}$, \\ Antonio de Castro Rodrigues ${ }^{\text {b }}$, Tania Mary Cestari ${ }^{\text {b }}$, Rogério Leone Buchaim ${ }^{\text {b,* }}$ \\ ${ }^{a}$ Faculty of Medicine, University of Marília (UNIMAR), Marília, SP, Brazil \\ ${ }^{\mathrm{b}}$ Department of Biological Sciences, Bauru School of Dentistry, University of São Paulo, Bauru, SP, Brazil \\ c University of the Sacred Heart, Bauru, SP, Brazil \\ ${ }^{\mathrm{d}}$ Center for the Study of Venoms and Venomous Animals (CEVAP), São Paulo State University (UNESP - Univ Estadual Paulista), Botucatu, SP, Brazil
}

\section{A R T I C L E I N F O}

\section{Article history:}

Received 4 April 2016

Received in revised form 6 July 2016

Accepted 7 July 2016

Available online 21 July 2016

\section{Keywords:}

Bone graft

Bone regeneration

Fibrin sealant

Laser therapy

Osseous defects

\begin{abstract}
A B S T R A C T
Autogenous bone grafts are used to repair bone defects, and the stabilization is needed for bone regeneration. Laser photobiomodulation is a modality of treatment in clinical practice for tissue regeneration, and it has therapeutic effects as an anti-inflammatory, analgesic and modulating cellular activity. The aim of the present study was to evaluate the effects of low-level laser therapy (LLLT) on an autogenous bone graft integration process stabilized with a new heterologous fibrin sealant. Forty rats were divided into two groups: Autogenous Fibrin Graft (AFG, $n=20$ ), in which a $5 \mathrm{~mm}$ dome osteotomy was conducted in the right parietal bone and the graft was adhered to the left side using fibrin sealant; and Autogenous Fibrin Graft Laser (AFGL, $n=20$ ), which was subjected to the same procedures as AFG with the addition of LLLT. The treatment was performed immediately following surgery and then three times a week until euthanasia, using an $830 \mathrm{~nm}$ laser $\left(30 \mathrm{~mW}, 6 \mathrm{~J} / \mathrm{cm}^{2}, 0.116 \mathrm{~cm}^{2}\right.$, $258.6 \mathrm{~mW} / \mathrm{cm}^{2}, 2.9 \mathrm{~J}$ ). Five animals from each group were euthanized at 10, 20, 30 and 40 days postoperative, and the samples were submitted to histomorphological and histomorphometric analysis. Partial bone regeneration occurred, with new bone tissue integrating the graft to the recipient bed and small areas of connective tissue. Comparative analysis of the groups at the same intervals revealed minor interfaces in group AFGL, with statistically significant differences $(p<0.05)$ at all of the analyzed intervals ( 10 days $p=0.0087,20$ days $p=0.0012$, 30 days $p<0.0001,40$ days $p=0.0142$ ). In conclusion, low-level laser therapy stimulated bone regeneration and accelerated the process of integration of autogenous bone grafts.
\end{abstract}

C 2016 Elsevier B.V. All rights reserved.

\section{Introduction}

Bone defects can occur as a result of oncological surgery, acute or chronic infections, trauma, and congenital malformations; grafts are one of the most commonly used methods for treating such defects [1]. Autogenous grafts are considered the gold standard for treating bone defects; however, graft fixation is essential to the process of bone regeneration [2,3]. Currently, the most common method for fixating onlay bone grafts is the use of titanium surgical screws, but this technique has disadvantages, such as complex fixation [4].

Due to these issues, there has been an increase in the use of alternative graft fixation methods. Cyanoacrylates were the first of such adhesives to be investigated. They have shown quick tissue adhesion and are

\footnotetext{
* Corresponding author at: Discipline of Anatomy, Department of Biological Sciences, Bauru School of Dentistry, University of São Paulo, Alameda Dr Octávio Pinheiro Brisola 9-75, Vila Nova Cidade Universitária, 17012-901 Bauru, SP, Brazil.

E-mail address: rogerio@fob.usp.br (R.L. Buchaim).
}

practical to use [5-8]. Other types of sealants have also been used, such as sealants derived from human blood, which present risks such as embolization, infection, and parvovirus B19 [9-11]. A new fibrin sealant derived from snake venom (Crotalus durissus terrificus) has been produced without the use of human blood. It presents all the properties of a biological and biodegradable sealant, with high adhesive capacity, and does not transmit infectious diseases [12,13].

In addition to graft fixation, professionals seek optimization of bone repair; low-level laser therapy has shown success and is an important ally in bone repair. Its use in many areas occurs primarily with the goal of modulating inflammation of scar tissue, leading to a decrease in the area of edema, stimulation of cell proliferation, and increased bone mineral density. This accelerates the tissue regeneration process, making it an effective technique for bone repair $[14,15]$.

The aim of the present study was to evaluate, by histomorphological and histomorphometric analysis, the effects of LLLT on an autogenous bone graft integration process stabilized with a new heterologous fibrin sealant. 


\section{Materials and Methods}

This study was approved by the animal research ethics committee (CEEPA) of the Bauru School of Dentistry, University of São Paulo, according to protocol no. 012/2012.

\subsection{Animals and Experimental Design}

The study was conducted with 40 adult male Wistar rats weighing an average of $312 \mathrm{~g}$. They were obtained from the bioterium of the Bauru School of Dentistry, University of São Paulo, Brazil.

The animals were randomly assigned to two experimental groups:

1. The Autogenous Fibrin Graft group (AFG, $n=20$ ): a dome osteotomy was conducted on the right parietal bone, which was decorticated with a no. 6 spherical drill. A fragment extracted from the right side was adhered to the left side with fibrin sealant.

2. Autogenous Fibrin Graft Laser group (AFGL, $n=20$ ): the same procedures were carried out as with the AFG, with the addition of LLLT.

\subsection{Fibrin Sealant}

Fibrin sealant derived from snake venom was supplied by the Center for the Study of Venoms and Venomous Animals (CEVAP) of UNESP. Its constituents and instructions for use are included in the patents (registration numbers BR1020140114327 and BR1020140114360), and it was prepared as suggested by Barros et al. [11]. The components of the fibrin sealant were stored in three Eppendorf $₫$ tubes and kept at $-80^{\circ} \mathrm{C}$. The components were reconstituted in liquid state at room temperature minutes before use in surgery. The sealant was applied according to the following protocol: the first bottle contained fibrinogen obtained from buffalo blood $(50 \mu \mathrm{l})$; the second contained calcium chloride $(20 \mu \mathrm{l})$; and the last had a thrombin-like fraction $(10 \mu \mathrm{l})$, totaling $80 \mu \mathrm{l}[12,16-19]$.

\subsection{Surgical Procedures}

The rats were sedated with xylazine $(10 \mathrm{mg} / \mathrm{kg}$, Anasedan, Ceva, Paulínia, SP, Brazil), in combination with ketamine $(50 \mathrm{mg} / \mathrm{kg}$, Dopalen, Ceva, Paulínia, SP, Brazil), via intramuscular injection. Using a shaver, the animals were trichotomized on the superior portion of the head, and the surgical area (frontoparietal region) was disinfected with $2 \%$ chlorhexidine. Next, with a number 15 scalpel blade, a longitudinal midline incision of approximately $20 \mathrm{~mm}$ was performed on the scalp over the sagittal suture of the skull. After the incision, all tissue was separated from the periosteum to expose the parietal bones.

In both treatment groups, a dome osteotomy was performed on the right parietal bone using a low-rotation $5 \mathrm{~mm}$ trephine drill (Neodent, Curitiba, PR, Brazil), under constant irrigation with $0.9 \%$ sodium chloride, extracting a round bone fragment and preserving the integrity of the dura mater and brain. On the left side, on the site that later received the autogenous graft, the parietal bone had previously been decorticated with nine perforations using a number 6 spherical drill (Fig. 1A and B). The autogenous bone collected from the right side was glued onto the left side using fibrin sealant (Fig. 1C and D) and left to dry for $30 \mathrm{~s}$, after which the periosteum and skin membranes were sutured by planes. The right defect was kept with the cavity covered by blood clot and was not examined.

\subsection{Laser Irradiation}

The animals in Group AFGL underwent laser irradiation (Laserpulse IBRAMED, Amparo, SP, Brazil) with continuous pulse GaAlAs (galliumaluminum-arsenide). The protocol was applied using a laser pen with a wavelength of $830 \mathrm{~nm}$, with $30 \mathrm{~mW}$ potency of optical power output, energy density of $6 \mathrm{~J} / \mathrm{cm}^{2}$, beam area of $0.116 \mathrm{~cm}^{2}$, power density of $258.6 \mathrm{~mW} / \mathrm{cm}^{2}$ and total energy of $2.9 \mathrm{~J}$. The duration of laser irradiation was $24 \mathrm{~s}$ per application site at four operative sites, distributed in a cross-shaped form on the graft. The laser irradiation was applied to the skin overlying the graft after closure of the wound, for a total application time of $96 \mathrm{~s}$ conducted immediately following surgery and three
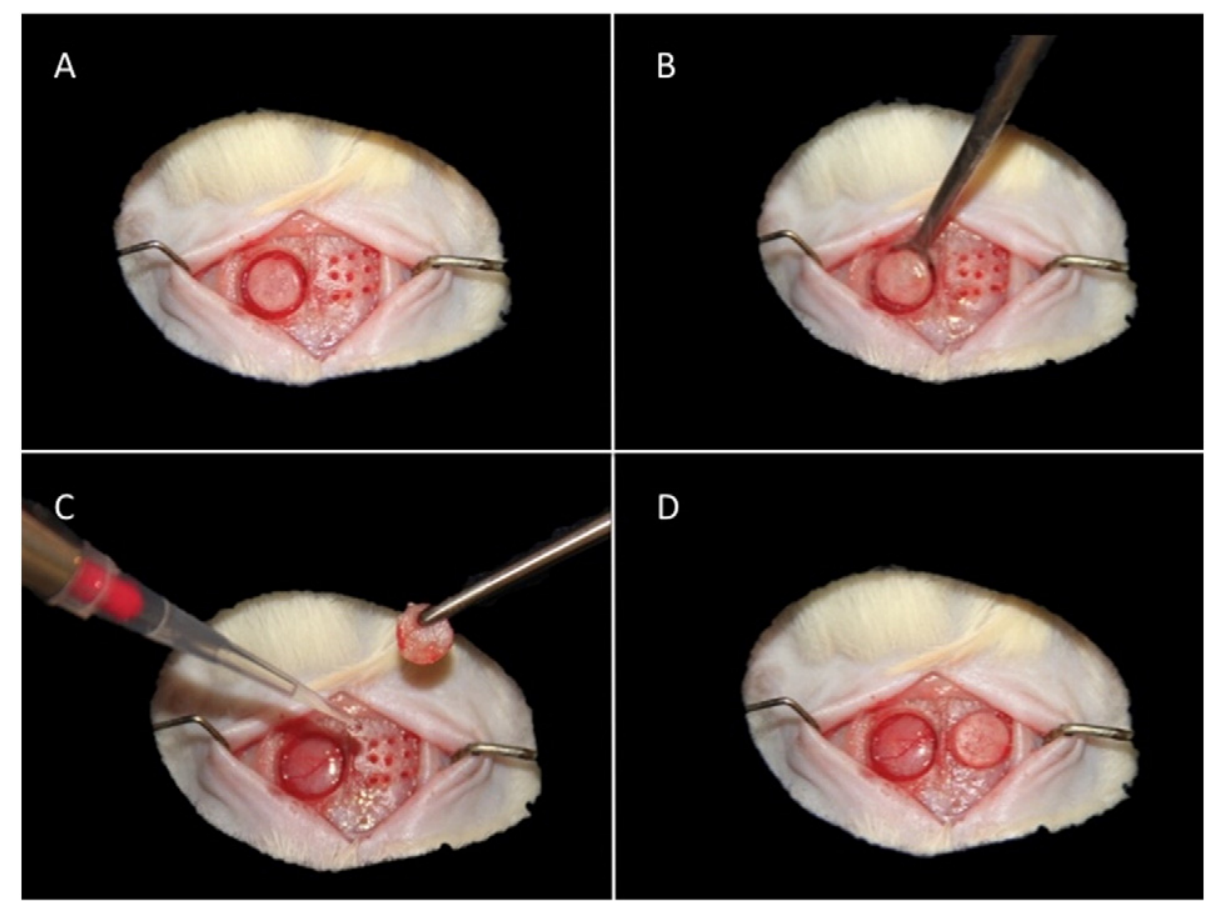

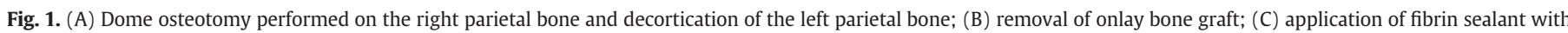
micropipette; (D) graft in position. 
times a week until euthanasia [14]. Laser beam emissions were self-calibrated by the device during all of the applications.

\subsection{Euthanasia and Histological Processing}

At $10,20,30$, and 40 days postoperative, five animals from each group were euthanized by anesthesia overdose. The calvarial bone was removed and the parietal bones were separated, preserving the supraperiosteal soft tissue. The pieces were fixated in $10 \%$ buffered formalin for $48 \mathrm{~h}$. The pieces were then washed in running water for $24 \mathrm{~h}$ and placed in 10\% EDTA (ethylene diamine tetraacetic acid), changed every seven days during the demineralization process. The demineralized pieces were then submitted to standard histological procedures, dehydrated in xylol, and embedded in Histosec (Merck ${ }^{\circledR}$, Darmstadt, Germany).

The histological sections were $5 \mu \mathrm{m}$ thick, taking into consideration the central region of the defect (greatest diameter), and the incisions were dyed with Masson's trichrome stain.

\subsection{Histomorphological and Histomorphometric Analysis}

The aim of the histomorphological analysis was to assess the incorporation of the grafts into the recipient bed, more specifically on the bone graft-calvaria interface, with a comparative analysis between the groups (AFG and AFGL) regarding differing tissue characteristics found on this interface. The histomorphometric analysis measured the total thickness of the surgical area (recipient bed + autogenous graft) at 11 different points along the graft $(0.5 \mathrm{~mm}$ intervals $)$ and the thickness of the interface between the recipient bed and the autogenous graft at the same points. Slide images were captured using an optical microscope (Olympus BX50, Tokyo, Japan) with an attached photographic camera (Olympus DP71, Tokyo, Japan).

\subsection{Statistical Analysis}

Quantitative analysis was carried out using Image Pro-Plus ${ }^{\circledR} 6.0$ software (Media Cybernetics, Bethesda, MD, USA). Total and interface thickness within the same group at different times were analyzed using ANOVA with Tukey's post hoc test $(p<0.05)$. Interface and total thickness, at the same postoperative times for both groups (AFG and AFGL), was analyzed using the unpaired $t$-test $(p<0.05)$. The software program used for statistical analysis was GraphPad Prism 5 (La Jolla, CA, USA).

\section{Results}

During euthanasia and histological preparation, including the first analysis period (10 days), the grafts in all specimens remained in the position in which they were stabilized in the experimental surgery and adhered to the recipient bed.

\subsection{Histomorphological Analysis}

Group AFG showed a very well-organized fibrous connective tissue at the initial periods of the repair process (10 and 20 days), which was gradually replaced by an osteoid matrix at the final periods of analysis ( 30 and 40 days), with areas of bone reabsorption and neoformation at the recipient bed-graft interface. There was no evidence of inflammatory responses at any of the analyzed periods. There was a slight amount of connective tissue and a considerable amount of neoformed bone tissue next to interlock areas and also at the remaining surface, especially at 40 days postoperative, joining the graft to the recipient bed over a large interface area, resulting in partial bone integration (Fig. 2).

Group AFGL showed more evident bone neoformation than Group AFG. At 40 days postoperative, a thin layer of connective tissue was observed in only some interface regions and interlock areas, and on most of these, there was bone tissue uniting the graft to the recipient bed. There was no evidence of inflammatory reactions at any of the analyzed periods (Fig. 3).

\subsection{Histomorphometric Analysis}

Considering Group AFG and all of the analyzed periods, there was a significant difference in total thickness between 20 and 30 days
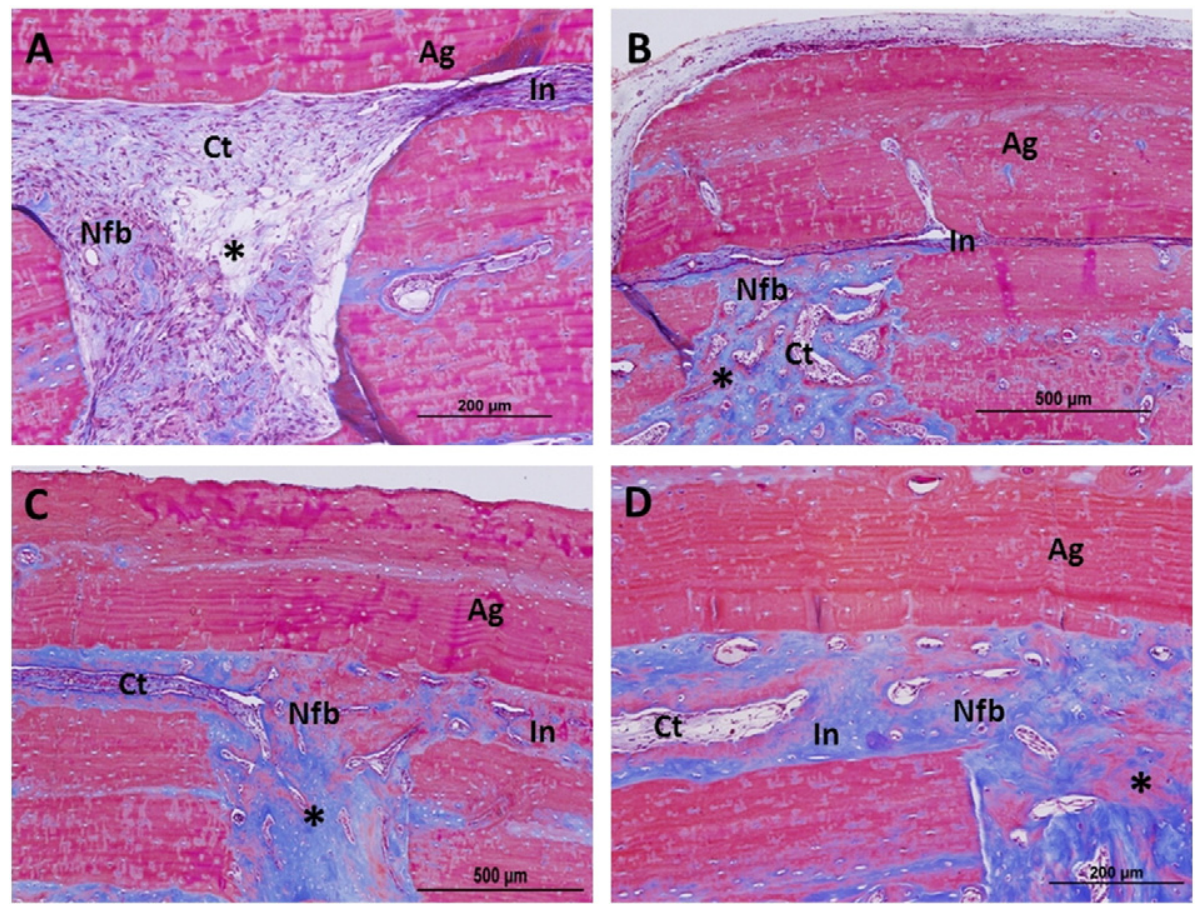

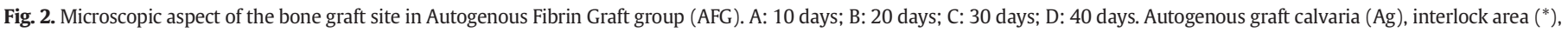
connective tissue $(\mathrm{Ct})$, newly formed bone $(\mathrm{Nfb})$, recipient bed-graft interface $(\mathrm{In})$. 

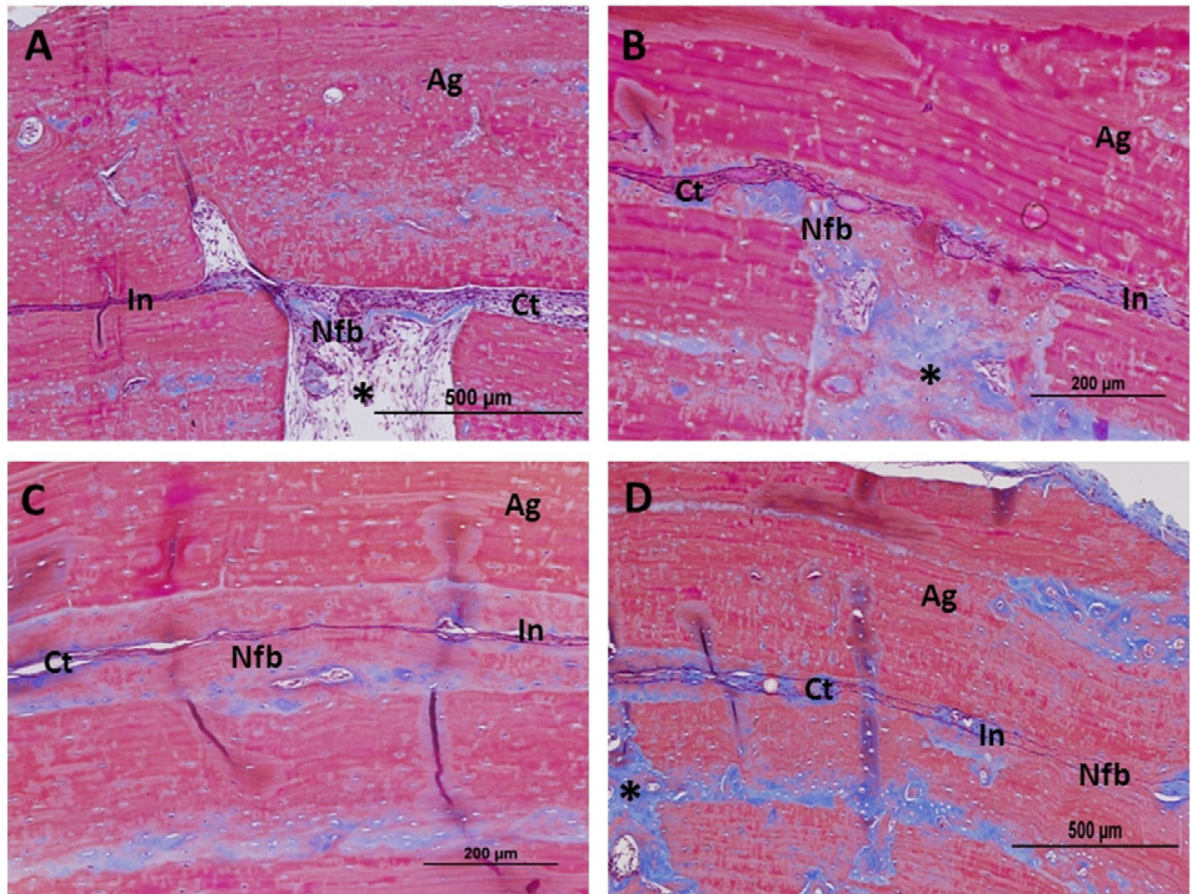

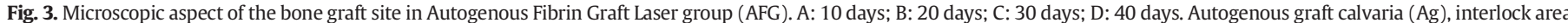
$\left({ }^{*}\right)$, connective tissue $(\mathrm{Ct})$, newly formed bone $(\mathrm{Nfb})$, recipient bed-graft interface $(\mathrm{In})$.
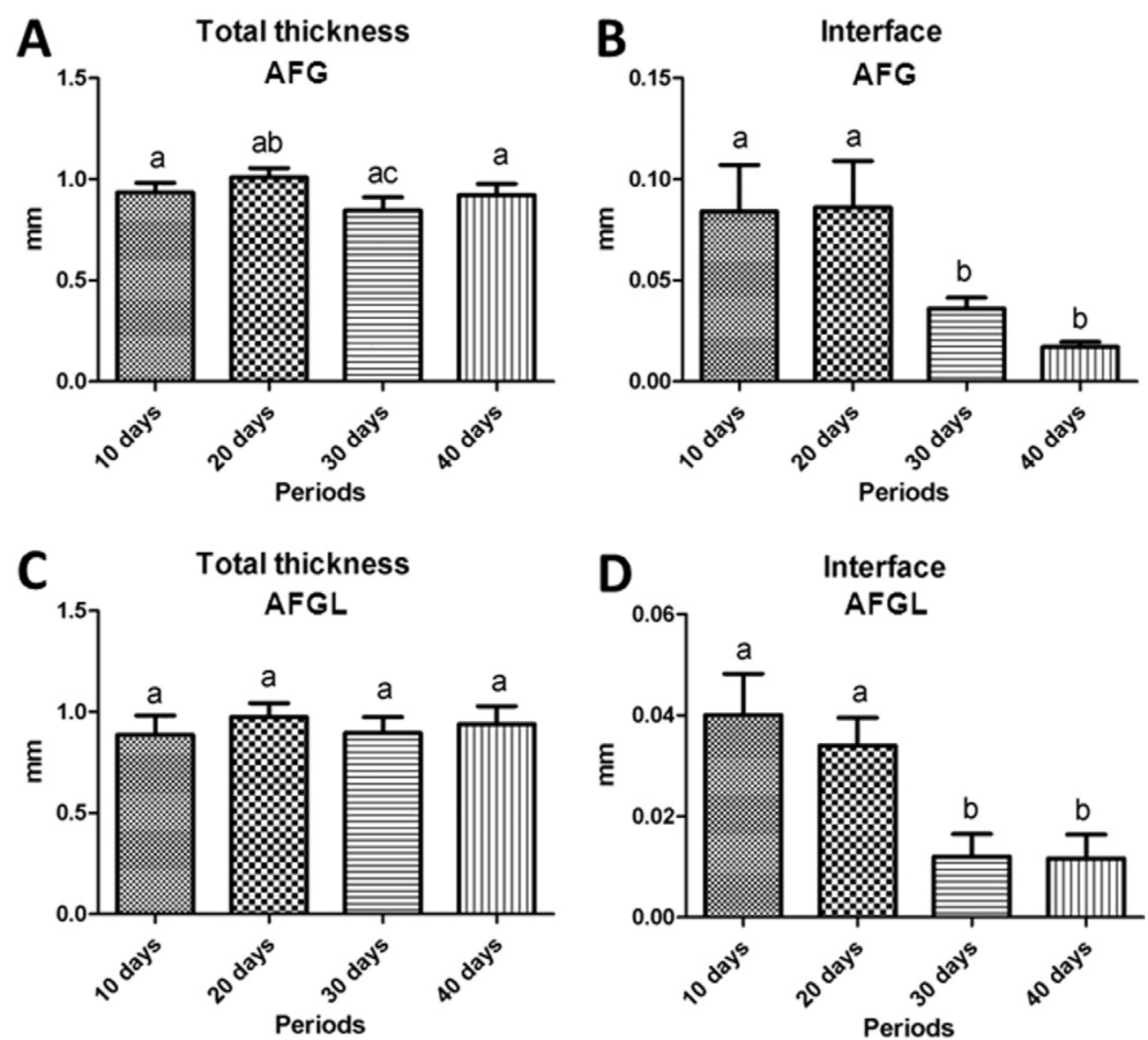

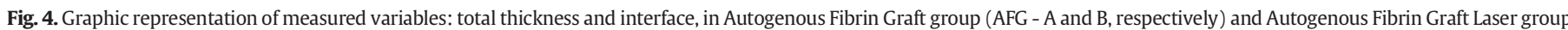
(AFGL - C and D, respectively). Different lowercase letters indicate a significant difference between periods $(p<0.05)$. 
Table 1

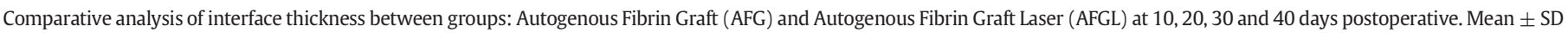
values.

\begin{tabular}{|c|c|c|c|c|}
\hline Groups & 10 days & 20 days & 30 days & 40 days \\
\hline Autogenous Fibrin Graft (AFG) & $0.084 \pm 0.023^{\mathrm{a}}$ & $0.086 \pm 0.023^{\mathrm{a}}$ & $0.036 \pm 0.005^{\mathrm{a}}$ & $0.017 \pm 0.002^{\mathrm{a}}$ \\
\hline Autogenous Fibrin Graft Laser (AFGL) & $0.040 \pm 0.008^{\mathrm{b}}$ & $0.034 \pm 0.005^{\mathrm{b}}$ & $0.012 \pm 0.004^{\mathrm{b}}$ & $0.011 \pm 0.003^{\mathrm{b}}$ \\
\hline
\end{tabular}

Presence of statistically significant difference between the groups in all periods analyzed (columns, $p<0.05$ ), indicated with different lower case letters $\left({ }^{\mathrm{a}, \mathrm{b}} \mathrm{b}\right)$.

postoperative $(1.01 \pm 0.045 \mathrm{~mm}$ and $0.846 \pm 0.064 \mathrm{~mm}$ respectively; Fig. 4A). There was a significant difference between interface thickness at $10(0.084 \pm 0.023 \mathrm{~mm})$ and 20 days postoperative $(0.086 \pm$ $0.023 \mathrm{~mm})$ when compared to $30(0.036 \pm 0.005 \mathrm{~mm})$ and 40 $(0.017 \pm 0.002 \mathrm{~mm})$ days postoperative (Fig. 4B).

No significant differences were observed in Group AFGL in terms of total thickness between the analyzed periods (Fig. 4C). Regarding interface, there was a significant difference between $10(0.04 \pm 0.008 \mathrm{~mm})$ and 20 days postoperative $(0.034 \pm 0.005 \mathrm{~mm})$ when compared to 30 $(0.012 \pm 0.004 \mathrm{~mm})$ and 40 days postoperative $(0.011 \pm 0.003 \mathrm{~mm}$; Fig. 4D).

Table 1 presents the results of comparative analysis of the groups at the same periods, showing minor interface in Group AFGL, with statistically significant differences $(p<0.05)$ at all of the analyzed periods ( 10 days $p=0.0087,20$ days $p=0.0012,30$ days $p<0.0001$, 40 days $p=0.0142$ ). In Table 2 , which shows comparison of total thickness in all analyzed periods, there was no significant difference $(p<0.05)$ between the groups ( 10 days $p=0.3647,20$ days $p=0.3602,30$ days $p=0.3018,40$ days $p=0.7089$ ).

\section{Discussion}

The aim of the present study was to evaluate the effects of low-level laser therapy on an autogenous bone graft stabilized with fibrin sealant derived from snake venom. The results showed that LLLT exhibited satisfactory results in bone repair, stimulating new bone formation and improving the stabilization grafts.

Autogenous bone graft was chosen for this study because it has been highlighted in the literature as possessing characteristics closest to the ideal (gold standard) when compared to other types of bone substitutes. Its main advantage is its potential to integrate with the recipient bed by providing viable cells for bone formation via osteogenesis, osteoinduction, and osteoconduction [20,21]. Previous studies that had only overlapped the graft without any fixing had demonstrated that, in several specimens, new bone neoformation occurred only at the central third of the graft, and their margins remained joined to the donor area by compact connective tissue [5].

The most common surgical technique for fixating autogenous grafts is titanium surgical screws, as they provide adequate stabilization. However, this surgical technique requires a lot of equipment, elevated costs, and surgical dexterity. Thus, the use of synthetic adhesives such as cyanoacrylates, polysiloxanes, and acetate polymers became the object of research in the search for immediate and consistent adhesion; however, due to their toxicity, these were considered inappropriate $[6,22,23]$.

The new heterologous fibrin sealant derived from snake venom presents the beneficial characteristics of other fibrin glues [11,16,24,25], and provided initial stability to the graft on the recipient bed, as long as it was not submitted to traction, and it is not made of rigid material such as plates and screws [26]. This stability provided the necessary conditions for bone formation within the graft-recipient bed interface. The tridimensional structure of the fibrin sealant provides an adequate scaffolding system for adhesion and proliferation of osteogenic cells, stimulating neoformation [27].

The use of a new heterologous fibrin sealant to stabilize bone blocks in both of the analyzed groups (AFG and AFGL) provided the necessary conditions for partial integration of the superimposed skull cap, especially in Group AFGL. This was observed in both the histological level, with no evidence of inflammatory responses caused by the sealant, and in the histomorphometric level, given the reduced interface thickness at all of the analyzed periods, contrary to the findings of similar studies conducted with cyanoacrylate [6]. The absence of inflammatory infiltrate demonstrates the biocompatibility of the new sealant, which does not derive from human blood and thus prevents tissue reactions and the release of anti-thrombin antibodies [27].

Several studies have demonstrated that physical methods can augment bone regeneration in order to enhance this healing process [2830]. Low-level laser therapy is effective mainly due to its positive effects on bone metabolism and consolidation of fractures via osteoblastic stimulation and increased bone mineral density [31-34]. In the initial phase of the bone neoformation process in the present study, the use of a laser was marked by increased angiogenesis and the presence of new blood vessels in the graft area, aiding the regeneration process. Histomorphometric analysis revealed significant differences in favor of Group AFGL when compared to Group AFG at all postoperative periods, with a thinner interface. The neovascularization and thermic and biological stimuli provided by LLLT can lead to better graft integration [32,35-38].

In the literature there are many different protocols featuring variations of energy density, wavelength and irradiation, with no accepted ideas about parameters. Several studies using a protocol similar to the present study (wavelength of $830 \mathrm{~nm}$ with $30 \mathrm{~mW}$ potency of optical power output, energy density of $6 \mathrm{~J} / \mathrm{cm}^{2}$ ) have shown beneficial effects of LLLT in healing, with organization of collagen fibers and repair tissue. Moreover, a continuous GaAlAs laser pulse, compared to other types, showed higher capability of penetrating tissues [39-42].

There are also studies reporting that even with the use of a different protocol (wavelength $810 \mathrm{~nm}$, output power $300 \mathrm{~mW}$, energy density $4 \mathrm{~J} / \mathrm{cm}^{2}$ ), LLLT had a positive effect on bone formation [43]. Despite evidence from some studies that several sessions are needed to achieve positive effects, there are also studies showing that the use of fewer sessions of LLLT is an alternative that deserves to be studied, since there is no standardized protocol for application [44].

The results of the present study demonstrate the potential of laser therapy for bone graft integration, even if the sealant still does not have a greater capacity for fixing than the screws, which can be considered a limitation. New perspectives are constantly emerging in this field,

Table 2

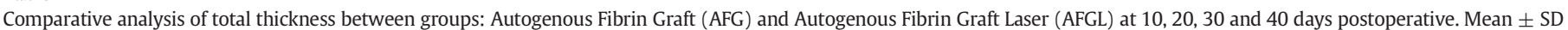
values.

\begin{tabular}{|c|c|c|c|c|}
\hline Groups & 10 days & 20 days & 30 days & 40 days \\
\hline Autogenous Fibrin Graft (AFG) & $0.934 \pm 0.047$ & $1.010 \pm 0.045$ & $0.846 \pm 0.064$ & $0.922 \pm 0.055$ \\
\hline Autogenous Fibrin Graft Laser (AFGL) & $0.887 \pm 0.094$ & $0.974 \pm 0.069$ & $0.896 \pm 0.078$ & $0.940 \pm 0.088$ \\
\hline
\end{tabular}

Absence of statistically significant difference between the groups in all periods analyzed (columns, $p<0.05$ ) 
such as the use of chemical treatments on extracted bone blocks, with the goal of reducing time of the total graft integration and, consequently, the duration of treatment as a whole [45].

\section{Conclusion}

Low-level laser therapy stimulated bone regeneration and accelerated the process of integration of autogenous bone graft.

\section{Conflict of Interest}

There was no conflict of interest.

\section{References}

[1] R.V. Silva, J.A. Camilli, C.A. Bertran, N.H. Moreira, The use of hydroxyapatite and autogenous cancellous bone grafts to repair bone defects in rats, Int. J. Oral Maxillofac. Surg. 34 (2005) 178-184.

[2] G.F. Rogers, A.K. Greene, Autogenous bone graft, J. Craniomaxillofac. Surg. 23 (2012) 323-327.

[3] K.Y. Lin, S.P. Bartlett, M.J. Yaremchuk, M. Fallon, R.F. Grossman, L.A. Whitaker, The effect of rigid fixation on the survival of onlay bone grafts: an experimental study, Plast. Reconstr. Surg. 86 (1990) 449-456.

[4] F.A. Quereshy, H.S. Dhaliwal, S.A. El, M.P. Horan, S.S. Dhaliwal, Resorbable screw fixation for cortical onlay bone grafting: a pilot study with preliminary results, J. Oral Maxillofac. Surg. 68 (2010) 2497-2502.

[5] J.C. Esteves, A.G. Borrasca, A.M. Aranega, I.R. Garcia Junior, O. Magro Filho, Histomorphometric analysis of the repair process of autogenous bone grafts fixed at rat calvaria with cyanoacrylate, J. Appl. Oral Sci. 19 (2011) 529-534.

[6] J.C. Esteves, J.M. Monteiro, A.M. Aranega, W. Betoni Junior, C.K. Sonoda, Utilization of ethyl cyanoacrylate and 2-octyl cyanoacrylate adhesives for autogenous bone graft fixation: histomorphometric study in rats, J. Oral Implantol. 40 (2014) 411-417.

[7] S. Saska, E. Hochuli-Vieira, A.M. Minarelli-Gaspar, M.F.R. Gabrielli, M.V. Capela, M.A.C. Gabrielli, Fixation of autogenous bone grafts with ethyl-cyanoacrylate glue or titanium screws in the calvaria of rabbits, Int. J. Oral Maxillofac. Surg. 38 (2009) 180-186.

[8] A. Odobasic, G. Krdzalic, M. Hodzic, S. Hasukic, A. Sehanovic, A. Odobasic, The role of fibrin glue polypropylene mesh fixation in open inguinal hernia repair, Med. Arch. 68 (2014) 90-93 (Sarajevo, Bosnia Herzegovina).

[9] G.C.-W. Kang, K.W.-E. Sng, A.G. Tay, Modified technique for frontal sinus obliteration using calvarial bone and Tisseel glue, J. Craniomaxillofac. Surg. 20 (2009) 528-531.

[10] M. Kawamura, M. Sawafuji, M. Watanabe, H. Horinouchi, K. Kobayashi, Frequency of transmission of human parvovirus B19 infection by fibrin sealant used during thoracic surgery, Ann. Thorac. Surg. 73 (2002) 1098-1100.

[11] L.C. Barros, R.S. Ferreira, S.R.C.S. Barraviera, H.O. Stolf, I.A. Thomazini-Santos, M.J.S. Mendes-Giannini, et al., A new fibrin sealant from Crotalus durissus terrificus venom: applications in medicine, J. Toxicol. Environ. Health B. Crit. Rev. 12 (2009) 553-571.

[12] R.L. Buchaim, J.C. Andreo, B. Barraviera, R.S. Ferreira Junior, D.V. Buchaim, G.M. Rosa Junior, et al., Effect of low-level laser therapy (LLLT) on peripheral nerve regeneration using fibrin glue derived from snake venom, Injury 46 (2015) 655-660.

[13] R. Barbizan, M.V. Castro, A.C. Rodrigues, B. Barraviera, R.S. Ferreira, A.L.R. Oliveira, Motor recovery and synaptic preservation after ventral root avulsion and repair with a fibrin sealant derived from snake venom, PLoS One 8 (2013), e63260.

[14] D. Gigo-Benato, S. Geuna, S. Rochkind, Phototherapy for enhancing peripheral nerve repair: a review of the literature, Muscle Nerve 31 (2005) 694-701.

[15] C.C. Alcântara, D. Gigo-Benato, T.F. Salvini, A.L.R. Oliveira, J.J. Anders, T.L. Russo, Effect of low-level laser therapy (LLLT) on acute neural recovery and inflammation-related gene expression after crush injury in rat sciatic nerve, Lasers Surg. Med. 45 (2013) 246-252.

[16] I.A. Thomazini-Santos, S.R.C.S. Barraviera, M.J.S. Mendes-Giannini, B. Barraviera, Surgical adhesives, J. Venom. Anim. Toxins 7 (2001) 159-171.

[17] L. Barros, A. Soares, F. Costa, V. Rodrigues, A. Fuly, J. Giglio, et al., Biochemical and biological evaluation of gyroxin isolated from Crotalus durissus terrificus venom, J. Venom. Anim. Toxins Incl. Trop. Dis. 17 (2011) 23-33.

[18] V.P.O. Gasparotto, F.C. Landim-Alvarenga, A.L.R. Oliveira, G.F. Simões, J.F. Lima-Neto, B. Barraviera, et al., A new fibrin sealant as a three-dimensional scaffold candidate for mesenchymal stem cells, Stem Cell Res. Ther. 5 (2014) 78.

[19] R. Seabra Ferreira, Autologous or heterologous fibrin sealant scaffold: which is the better choice? J. Venom. Anim. Toxins Incl. Trop. Dis. 20 (2014) 31.

[20] R. Kontio, Treatment of orbital fractures: the case for reconstruction with autogenous bone, J. Oral Maxillofac. Surg. 62 (2004) 863-868.

[21] S.S. Jensen, N. Broggini, E. Hjørting-Hansen, R. Schenk, D. Buser, Bone healing and graft resorption of autograft, anorganic bovine bone and beta-tricalcium phosphate. A histologic and histomorphometric study in the mandibles of minipigs, Clin. Oral Implants Res. 17 (2006) 237-243.
[22] S.M. Sheta, T. Hida, B.W. McCuen, Cyanoacrylate tissue adhesive in the management of recurrent retinal detachment caused by macular hole, Am J. Ophthalmol. 109 (1990) 28-32.

[23] F.J. Papatheofanis, R. Barmada, The principles and applications of surgical adhesives, Surg. Annu. 25 (Pt 1) (1993) 49-81.

[24] G.H. Epstein, R.A. Weisman, S. Zwillenberg, A.D. Schreiber, A new autologous fibrinogen-based adhesive for otologic surgery, Ann. Otol. Rhinol. Laryngol. 95 (1986) 40-45.

[25] B.R. Davis, G.K. Sándor, Use of fibrin glue in maxillofacial surgery, J. Otolaryngol. 27 (1998) 107-112

[26] K. Endres, R. Marx, J. Tinschert, D.C. Wirtz, C. Stoll, D. Riediger, et al., A new adhesive technique for internal fixation in midfacial surgery, Biomed. Eng. Online 7 (2008) 16.

[27] E.G. Machado, J.P.M. Issa, F.A.T. de Figueiredo, G.R. Dos Santos, E.A. Galdeano, M.C Alves, et al., A new heterologous fibrin sealant as scaffold to recombinant human bone morphogenetic protein-2 (rhBMP-2) and natural latex proteins for the repair of tibial bone defects, Acta Histochem. 117 (2015) 288-296.

[28] K.T. Pomini, J.C. Andreo, A. de C. Rodrigues, J.B. de O Gonçalves, L.R. Daré, I.J.S German, et al., Effect of low-intensity pulsed ultrasound on bone regeneration: biochemical and radiologic analyses, J. Ultrasound Med. 33 (2014) 713-717.

[29] A.C.M. Renno, P.A. McDonnell, N.A. Parizotto, E.-L. Laakso, The effects of laser irradiation on osteoblast and osteosarcoma cell proliferation and differentiation in vitro, Photomed. Laser Surg. 25 (2007) 275-280.

[30] S. Kazem Shakouri, J. Soleimanpour, Y. Salekzamani, M.R. Oskuie, Effect of low-leve laser therapy on the fracture healing process, Lasers Med. Sci. 25 (2010) 73-77.

[31] M. Khadra, S.P. Lyngstadaas, H.R. Haanaes, K. Mustafa, Effect of laser therapy on attachment, proliferation and differentiation of human osteoblast-like cells cultured on titanium implant material, Biomaterials 26 (2005) 3503-3509.

[32] A. Stein, D. Benayahu, L. Maltz, U. Oron, Low-level laser irradiation promotes proliferation and differentiation of human osteoblasts in vitro, Photomed. Laser Surg. 23 (2005) 161-166.

[33] A.L.B. Pinheiro, L.G.P. Soares, M.C.T. Cangussú, N.R.S. Santos, A.F.S. Barbosa, L. Silveira Júnior, Effects of LED phototherapy on bone defects grafted with MTA, bone morphogenetic proteins and guided bone regeneration: a Raman spectroscopic study, Lasers Med. Sci. 27 (2012) 903-916.

[34] R. Buchaim, M. Rosso, J. Andreo, D. Buchaim, R. Okamoto, A. Rodrigues, et al., A new anionic bovine tendon as scaffold for the repair of bone defects: a morphological, histomorphometric and immunohistochemical study, Br. J. Med. Med. Res. 10 (2015) 1-11

[35] I. Garavello-Freitas, V. Baranauskas, P.P. Joazeiro, C.R. Padovani, M. Dal Pai-Silva, M.A da Cruz-Höfling, Low-power laser irradiation improves histomorphometrical parameters and bone matrix organization during tibia wound healing in rats, J Photochem. Photobiol. B 70 (2003) 81-89.

[36] A. Iatecola, B. Barraviera, R.S. Ferreira, G.R. dos Santos, J.I. Neves, M.R. da Cunha, Use of a new fibrin sealant and laser irradiation in the repair of skull defects in rats, Braz. Dent. J. 24 (2013) 456-461.

[37] R. Fekrazad, M. Sadeghi Ghuchani, M.B. Eslaminejad, L. Taghiyar, K.A.M. Kalhori, M.S. Pedram, et al., The effects of combined low level laser therapy and mesenchymal stem cells on bone regeneration in rabbit calvarial defects, J. Photochem. Photobiol. B 151 (2015) 180-185.

[38] M.J.H. Nagata, C.S. Santinoni, N.M. Pola, N. de Campos, M.R. Messora, S.R.M. Bomfim, et al., Bone marrow aspirate combined with low-level laser therapy: a new therapeutic approach to enhance bone healing, J. Photochem. Photobiol. B 121 (2013) 6-14.

[39] D.V. Buchaim, A.C. Rodrigues, R.L. Buchaim, B. Barraviera, R.S. Junior, G.M. Junior et al., The new heterologous fibrin sealant in combination with low-level laser therapy (LLLT) in the repair of the buccal branch of the facial nerve, Lasers Med. Sci. 31 (2016) 965-972.

[40] F.N. Ferreira, J.O. Gondim, J.J. Neto, P.C. Dos Santos, K.M. de Freitas Pontes, L.M. Kurita, et al., Effects of low-level laser therapy on bone regeneration of the midpalatal suture after rapid maxillary expansion, Lasers Med. Sci. 31 (2016) 907-913.

[41] C.C. Medalha, A.L. Santos, S.O. Veronez, K.R. Fernandes, A.M. Magri, A.C. Renno, Low level laser therapy accelerates bone healing in spinal cord injured rats, J. Photochem. Photobiol. B 159 (2016) 179-185.

[42] M.S. Moreira, I.T. Velasco, L.S. Ferreira, S.K.K. Ariga, D.F. Barbeiro, D.T. Meneguzzo, et al., Effect of phototherapy with low intensity laser on local and systemic immunomodulation following focal brain damage in rat, J. Photochem. Photobiol. B 97 (2009) 145-151.

[43] A.A. Rasouli Ghahroudi, A.R. Rokn, K.A. Kalhori, A. Khorsand, A. Pournabi, A.L. Pinheiro, et al., Effect of low-level laser therapy irradiation and Bio-Oss graft material on the osteogenesis process in rabbit calvarium defects: a double blind experimental study, Lasers Med. Sci. 29 (2014) 925-932.

[44] L. Marques, L.A. Holgado, L.A. Francischone, J.P. Ximenez, R. Okamoto, A. Kinoshita, New LLLT protocol to speed up the bone healing process-histometric and immunohistochemical analysis in rat calvarial bone defect, Lasers Med. Sci. 30 (2015) 1225-1230.

[45] M.L.R. de Rezende, P.T.G. Coesta, R.C. de Oliveira, S. Salmeron, A.C.P. Sant'Ana, C.A Damante, et al., Bone demineralization with citric acid enhances adhesion and spreading of preosteoblasts, J. Periodontol. 86 (2015) 146-154. 